\title{
Herhaaldelijk geheugenverlies
}

\author{
Jan Schakelaar
}

\section{Bespreking}

Transient global amnesia (TGA) is een neurologische aandoening waarbij tijdelijk geheugenverlies optreedt. De aanval begint met een plotselinge anterograde amnesie: patiënten zijn niet meer in staat om nieuwe herinneringen te vormen. Zowel de omgeving als de patiënt zelf zijn vaak angstig en bezorgd, en vrezen dat het een beroerte is. Bij neurologisch onderzoek is er geen afwijking. Een aanval duurt meestal korter dan tien uur en verdwijnt langzaam. De incidentie is 5 tot 10 per 100.000 patiënten per jaar. Slechts één op de tien patiënten krijgt vaker een aanval. ${ }^{1}$

De zeven diagnostische criteria voor TGA zijn: ${ }^{2}$

- aanwezigheid van anterograde geheugenverlies;

- aanwezigheid van een betrouwbare heteroanamnese;

- geen verminderd bewustzijn of identiteitsverlies;

- alleen geheugenverlies en geen andere cognitieve stoornissen;

- geen focale neurologische of epileptische symptomen;

- geen recente geschiedenis van hoofdletsel of collaps;

- verdwijnen van de verschijnselen binnen 24 uur.

Alle diagnostische criteria waren bij de tweede aanval aanwezig. Hoewel er geen ooggetuigenverslag is van de eerste aanval (en deze derhalve niet voldeed aan alle diagnostische criteria) lijkt het waarschijnlijk dat zich ook toen een TGA heeft voorgedaan. De belangrijkste ziektebeelden in de differentiaaldiagnose zijn

\section{Samenvatting}

Schakelaar JH. Herhaaldelijk geheugenverlies. Huisarts Wet 2010;53(2):111-2.

Deze klinische les beschrijft een 54-jarige man die binnen een jaar tweemaal een episode meemaakte van transient global amnesia (TGA). TGA is een klassiek neurologisch beeld met een lage incidentie. Het verdwijnt meestal binnen een dag zonder restverschijnselen en herhaalt zich zelden, maar de patiënt en diens omgeving maken zich meestal grote zorgen. Zij denken vaak dat het een beroerte is. De huisarts is goed in staat om, op basis van zeven criteria bij anamnese en lichamelijk onderzoek en met kennis van de differentiaaldiagnose, zelf de diagnose te stellen. Bij onzekerheid over dit tamelijk zeldzame ziektebeeld kan overleg met de neuroloog uitsluitsel geven.

Huisartsenpraktijk Paladijnenweg, Paladijnenweg 30, 3813 DJ Amersfoort: J.H. Schakelaar, huisarts

Correspondentie: jschakelaar@kpnplanet.nl

Mogelijke belangenverstrengeling: niets aangegeven.

\section{Op een ochtend}

ledere dag begin ik voor het spreekuur met het lezen van de eConsulten die verzonden zijn vanaf onze website. Afgelopen februari kreeg ik op een morgen dit eConsult van een van mijn patiënten: 'Een tijdje geleden ben ik bij u geweest voor een periode van geheugenverlies. Ik wist niet hoe oud ik was, welk jaar het was. Afgelopen vrijdag heb ik het weer gehad. Ik wist niet welk jaar het was. Tijdelijk verlies van een deel van mijn kortetermijngeheugen. Het duurde korter dan de eerste keer. Ik herkende het meteen. Ik kon niet verder met het gesprek waar ik mee bezig was. De afgelopen week heb ik lichte hoofdpijn gehad'.

De patiënt die mij deze mail stuurde is een 54-jarige man. Ik ken hem met een licht verhoogde bloeddruk waarvoor hij 1 dd metoprolol 100 mg gebruikt. Hij heeft overgewicht (BMI 33). In 1997 heeft hij een uvulaoperatie ondergaan wegens obstructief slaapapneusyndroom (OSAS).

De man had mij in het jaar daarvoor ook al eens geconsulteerd. Destijds had hij op een zaterdagochtend, terwijl hij op de computer aan het werk was, plotseling opgemerkt dat er iets verkeerd was. Er was niemand in de buurt. Hij was zijn begrip van tijd kwijt; hij wist niet welk jaar het was en kon er ook niet achterkomen. Later, na de aanval, dacht hij dat hij het huis doorzocht had om uit te vinden welk jaar het was, en dat misschien ook wel ontdekt had (via de krant of in zijn agenda) maar het onmiddellijk weer vergeten was. Voor zover hij wist had hij geen neurologisch verschijnsel gehad. Langzaam was zijn geheugen weer teruggekomen.

Op de morgen van het eConsult heb ik hem opgebeld. De patiënt vertelde dat het deze tweede keer op zijn kantoor was gebeurd. Er waren nu getuigen. Zij vertelden hem later dat hij herhaaldelijk dezelfde vragen had gesteld over de tijd en de datum. Hij was verder helemaal helder geweest. De aanval had kort geduurd, ongeveer twintig minuten. Niemand had automatische bewegingen of staren opgemerkt en er waren geen zichtbare neurologische uitvalsverschijnselen opgetreden. De dag na het incident had patiënt een gesprek met een medewerker. Deze vertelde hem dat zij samen de dag daarvoor precies hetzelfde gesprek hadden gehad; de patiënt kon zich daar niets meer van herinneren. Beide aanvallen waren voorafgegaan door een stressvolle gebeurtenis.

Ik was wat ongerust na de tweede aanval. In het verleden had ik tweemaal een patiënt gezien met transient global amnesia, maar dit keer maakten de hoofdpijn (later begreep ik dat dat een vaak voorkomend begeleidend symptoom is) en vooral het herhaalde optreden mij onzeker. Ik nam contact op met de dienstdoende neuroloog. Zij onderzocht patiënt de volgende dag en liet een CT-scan maken. Ook de cardioloog bekeek de patiënt, omdat deze soms last had van hartkloppingen - iets waarvan ik niet op de hoogte was. De CT-scan liet geen afwijkingen zien. Ook de cardioloog vond in de weken daarop geen afwijkingen.

De neuroloog concludeerde dat de symptomen 'zeer goed pasten bij de diagnose TGA'. De patiënt en ik waren opgelucht 


\section{De kern}

- Transient global amnesia (TGA) is een klassiek neurologisch beeld dat zelden voorkomt in de huisartsenpraktijk.

- TGA verdwijnt meestal binnen een etmaal zonder blijvende schade, en herhaalt zich zelden.

- De huisarts kan de diagnose goed zelf stellen op basis van zeven klinische criteria. Bij twijfel kan hij een neuroloog raadplegen.

- Het belangrijkste is de patiënt en diens omgeving voor te lichten en gerust te stellen.

delier of acute confusional state (ACS), transient epileptic amnesia (TEA), transient ischaemic attack (TIA), complex partial seizure (CPS) en psychogenic amnesia (PA). 2,3

Bij het delier of ACS is er een wisselend bewustzijnsniveau, vaak in combinatie met hallucinaties. TEA komt vaak voor bij het ontwaken en omvat zowel een retrograde als anterograde amnesie; vaak zijn er ook epileptische verschijnselen zoals smakken of staren. Hetzelfde geldt voor CPS, in tegenstelling tot patiënten met TGA die vaak alert en helder zijn; CPS wordt bovendien vaak voorafgegaan door een aura. TIA's gaan zeer vaak gepaard met neurologische verschijnselen.

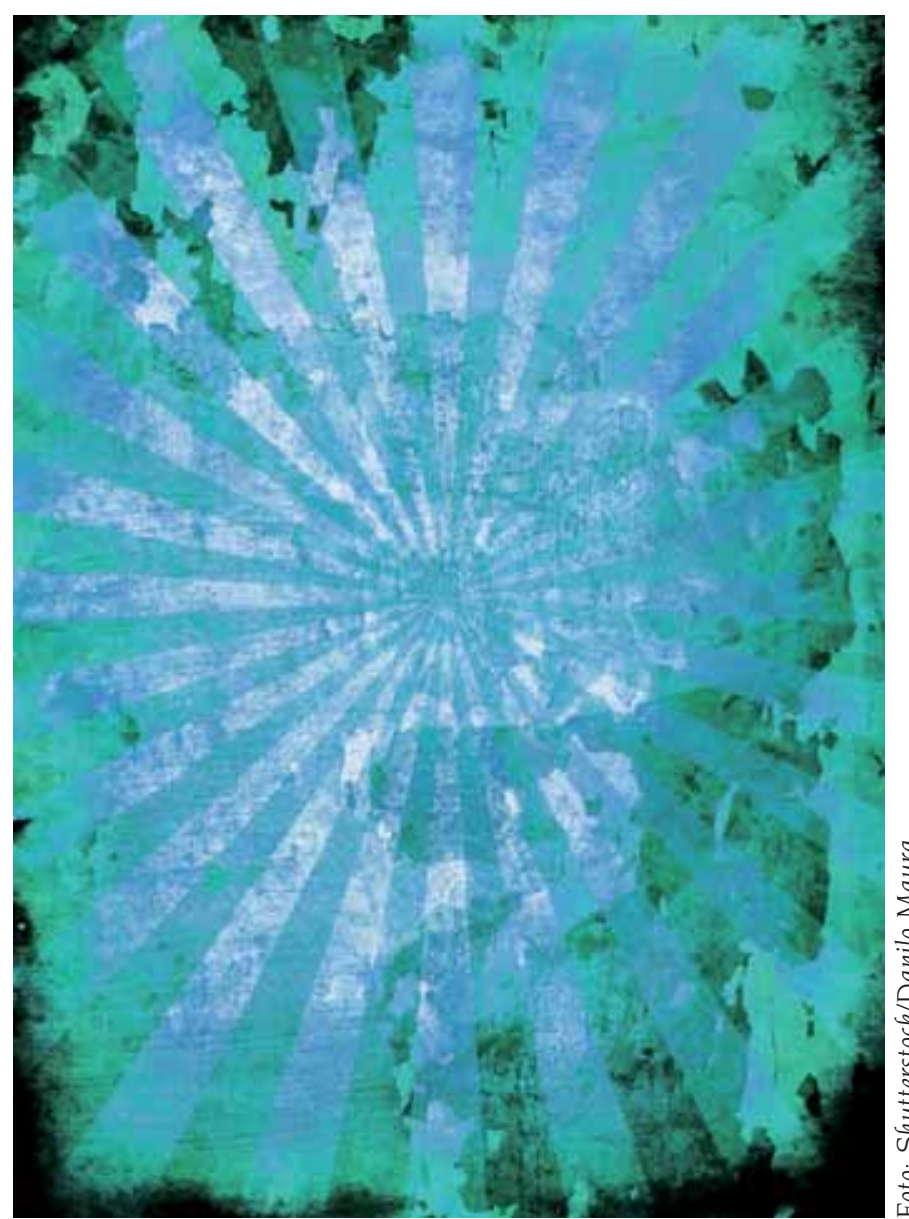

\section{TGA voor de huisarts}

TGA is een van de klassieke neurologische ziektebeelden. De kans op herhaling is klein: in een review van 142 gevalsbeschrijvingen schatte men de kans dat een TGA zich binnen een jaar zou herha-

\begin{abstract}
Schakelaar JH. Repeated memory loss. Huisarts Wet 2010; 53(2):111-2.

This clinical lesson describes a 54-year-old man who experienced two episodes of transient global amnesia in 2 years. Transient global amnesia is a classic neurological picture with a low incidence. It usually disappears within 24 hours without residual signs and seldom recurs, but patients and their friends and relatives are often concerned that it is a stroke. The general practitioner can make the diagnosis based on seven criteria established from the history and physical examination and with knowledge of the differential diagnosis. If there is diagnostic uncertainty about this relatively rare disorder, a neurologist should be consulted.
\end{abstract}

len op 5,8\%. ${ }^{1}$ Mijn patiënt is in dit opzicht dus vrij uitzonderlijk. Huisartsen komen TGA niet vaak tegen. Wanneer een patiënt zich meldt, moet de huisarts deze zo snel mogelijk zien, in ieder geval binnen enkele uren. Dit vloeit logisch voort uit de differentiaaldiagnose, maar is ook van belang omdat zich vaak een grote ongerustheid meester maakt van de patiënt en diens omgeving. De meeste patiënten denken dat er sprake is van een 'beroerte'. Dat is een begrijpelijke gedachte. Overleg met de neuroloog is vaak gewenst vanwege de geringe ervaring die huisartsen hebben met dit ziektebeeld.

Wanneer er sprake lijkt van een TGA, moeten de huisarts en de patiënt afspraken maken over het vervolgen van het beloop. Omdat de diagnose TGA alleen gesteld mag worden als de verschijnselen binnen 24 uur verdwijnen, ligt het voor de hand het vervolgcontact pas na die 24 uur te plannen. Maar bij twijfel of grote ongerustheid bij patiënt en omgeving is het verstandig ook een vervolgcontact aan te bieden binnen enkele uren na het eerste contact.

Als er een betrouwbare heteroanamnese is, als er noch bij de anamnese noch bij het lichamelijk onderzoek neurologische verschijnselen zijn of zijn geweest, als er geen hoofdletsel is, een helder bewustzijn en alleen anterograde amnesie, en als ten slotte de verschijnselen binnen 24 uur verdwenen zijn, kan de huisarts prima de diagnose stellen. Een belangrijke taak is het herkennen en uitleggen van de verschijnselen, en het geruststellen van de patiënt en diens naasten: de patiënt kan nieuwe informatie tijdelijk niet goed vastleggen en vasthouden, maar er is geen gevaar voor blijvende schade.

\section{Literatuur}

1 Quinette P, Guillery-Girard B, Dayan J, De la Sayette V, Marquis S, Viader F, et al. What does transient global amnesia really mean? Review of the literature and thorough study of 142 cases. Brain 2006; 129:1640-58.

2 Owen D, Paranandi B, Sivakumar R, Seevaratnam M. Classical diseases revisited: transient global amnesia. Postgrad Med J 2007;83:236-9

3 Shekhar R. Transient global amnesia: a review. Int J Clin Pract 2008;62:939-42 